\title{
Effect of germination duration on nutritional and functional properties of sorghum (Sorghum bicolor): The case of Girana and Miskr varieties
}

\author{
Hana Derbew ${ }^{*}$ and Demewez Moges ${ }^{1}$ \\ ${ }^{1}$ Faculty of Chemical and Food Engineering, Bahir Dar Institute of Technology, Bahir Dar University
}

\begin{abstract}
The effect of germination duration on proximate, minerals, anti-nutritional factors and functional properties of two local sorghum varieties (Girana and Miskr) were investigated. A $2 * 3 * 2$ full factorial design was used to conduct the experiment. Sorghum varieties were soaked for 24 hours at room temperature and germinated for 24,48 and 72 hours in duplicate. The germinated and control sorghum grains were milled. The analysis and measurement of dependent variables were done in triplicate. The collected data were subjected to analysis of variance using SPSS statistical software. On average after 72 hours germination $9.68 \%$ and $9.52 \%$ reduction in $\mathrm{pH}$ and $34.5 \%$ \& $16.6 \%$ increase in TTA was observed which may improve product stability and mineral absorption. Similarly crude protein content showed a significant $(\mathrm{p}<0.05)$ increase from $10.35 \pm 0.04 \%$ to $12.59 \pm 0.15 \%$ and $10.17 \pm 0.02$ to $12.75 \pm 0.136 \%$ for Girana and Misker varieties, respectively. A significant $(\mathrm{p}<0.05)$ decrease in crude fat and carbohydrate content was observed for both varieties that in turn brought about a decrease in the average energy value of nearly $8 \mathrm{kcal} / 100 \mathrm{gm}$ of sorghum flour. Germination resulted in a significant $(\mathrm{p}<0.05)$ average $50 \%$ and $53 \%$ reduction in phytate and tannin content of Girana and Misker varieties respectively. Germination shows a significant $(p<0.05)$ increase of iron from $7.15 \pm 0.03$ to $7.51 \pm 0.23$ and from $7.42 \pm 0.1$ to $7.85 \pm 0.17$ at 48 hours for Girana and Misker varieties respectively. Moreover, phytate/zinc molar ratio significantly decreased well below 15 for both varieties. Improvement in functional properties of sorghum as measured by WAI, WSI and viscosity was also observed after 72 hours germination.
\end{abstract}

Key words: Anti-nutritional factor, bioavailablity, functional properties, mineral composition, proximate, and sorghum

DOI: http://dx.doi.org/10.4314/ejst.v10i3.2

\section{INTRODUCTION}

Sorghum (Sorghum bicolor) is considered as one of the most important food crops in the world, following wheat, rice, maize and barley (FAO, 2006). Because it is less dependent on rainfall, and therefore, less affected by fluctuations in environmental conditions, sorghum is an important food crop in the semi-arid regions of Ethiopia. It has diverse uses, including human consumption and animal feed. Processed sorghum seeds or flour is found to be important source of calories and proteins to the vast majority of the population who relies on sorghum as staple food (FAO, 2006). Sorghum is used for preparing injera, porridges, flat bread, alcoholic and non-alcoholic beverages, and specialty foods such as popped grain (Asfaw Adugna et al., 2005).

Unfortunately, sorghum has low nutritional value and inferior organoleptic qualities due to the presence of anti-nutritional factors which form complexes with food ingredients that reduce digestibility of protein and bioavailability of

*Corresponding author: hanade06@gmail.com

(C) This is an Open Access article distributed under the terms of the Creative Commons Attribution License (http://creativecommons.org/licenses/CC BY4.0). 
minerals (Davidson et al., 1979). The factors responsible for poor sorghum protein digestibility are grain organizational structure, tannin and phytic acid, and starch and non-starch polysaccharides. The tannin-protein interaction in sorghum involves hydrogen bonding and hydrophobic interactions. Sorghum prolamins (proline-rich proteins) bind strongly to sorghum tannins and result in reduced protein digestibility (Gibson et al., 2010).

Bioavailability is a general term that refers to how well a nutrient can be absorbed and used by the body. It can be affected by many factors such as the presence of anti-nutrients, for example, phytates, oxalates, tannins and polyphenols in foods (Gibson et al., 2010). Phytate is a phosphorus containing compound that binds with minerals and inhibits mineral absorption. The presence of phytate in foods has been associated with reduced mineral absorption due to high density, negatively charged phosphate groups which form very stable complexes with mineral ions. The complex formed between phytate and minerals causes nonavailability for intestinal absorption of critical nutrients such as zinc, iron, and calcium (Weaver and Kannan, 2000; Walter et al., 2002). And such deficits in iron, zinc, and calcium can have farreaching adverse consequences on growth, health, and cognitive development during childhood (Gibson et al., 2010).

There are two major ways to improve mineral bioavailability and nutritional quality, namely reducing the anti-nutrient factors content in the foods or adding extra nutrients in the fortification process. However, in low-income countries like Ethiopia, the inhibitory effect of anti-nutritionals on mineral bioavailability and other nutrients quality in cereal - and/or legume - is unlikely to be attenuated by fortification. Instead, reducing anti-nutrients of staple cereals by low-cost household technologies such as germination, soaking and fermentation may be a more feasible alternative to enhance nutrient bioavailability and to improve protein content and quality as well as flavour profile, colour and functional property of the products (Gibson et al., 2010; Shashi et al., 2007; Rooney and Waniska, 2004). In addition, some researchers suggest household level food processing techniques that noticeably enhance the palatability of the food by improving functional properties of seeds (Atwell et al., 1988). Previous researchers also reported different varieties of sorghum that respond differently to germination treatment (Raihanatu et al., 2011).

This research was therefore conducted to investigate the potential of germination as low-cost household technology to improve nutritional and functional property of two local sorghum varieties.

\section{MATERIALS AND METHODS}

\section{Experimental Setup and Sample Preparation}

The experiment consisted of a $2 * 3 * 2$ full factorial design with two sorghum Varieties (Viz. Miskr and Girana), a control and three durations of germination $(0,24,48$ and 72 hours) applied to the sorghum varieties with two replications of the entire experiment.

The two sorghum varieties obtained from Sirinka Agricultural Research Center (North Wollo zone, Amhara region) were cleaned manually to remove broken kernels, husk, stems, damaged grain, stone, dust, unwanted materials, undersized and immature grains and other extraneous materials. 
The cleaned sorghum grains were divided into two portions. The first portion, which was not subjected to germination, was milled and packed in airtight plastic bags and served as a control. The second sorghum grains portion were washed three times using deionised water. Then, the cleaned and washed sorghum grains were soaked in a volume of water 3 times the weight of grains (3:1) for 24 hours at $25^{\circ} \mathrm{C}$ in drying cabinet with plastic containers (Egli et al., 2002). Then, the steeping water was drained off and the grain was washed twice using deionised water to protect the growth of microorganisms during germination. The soaked and washed sorghum grains were again divided into three portions (Treatment samples) and germinated for 24, 48 and 72 hours in duplicate. The treatment samples were covered with wet clean cloth and placed in a plastic sieves. The content was left in drying cabinet at $25^{\circ} \mathrm{C}$ and watered two times a day to enhance the germination process. Finally, the sorghum sprouts were washed thoroughly to reduce the sour taste, and then the rootlets were removed by pounding. The germinated and dried sorghum grain samples were milled to pass through a $710 \mu \mathrm{m}$ aperture size of a laboratory test sieve and were stored packed in airtight plastic bags until further analysis.

\section{Analysis of chemical composition}

\section{Determination $\mathrm{pH}$}

The $\mathrm{pH}$ of the samples was determined following Pearson (1971). Accordingly, $10 \mathrm{~g}$ of the germinated flour was added to $30 \mathrm{ml}$ of distilled water and stirred for $10 \mathrm{~min}$. The $\mathrm{pH}$ of the slurry was determined by dipping the electrode of the $\mathrm{pH}$ meter (HANNA instrument) in the mixture. The $\mathrm{pH}$ of the fermented samples was determined by dipping the electrode in the homogenized fermented slurries at the end of each fermentation period. Triplicate determinations were made in all cases. The $\mathrm{pH}$ meter was calibrated using $\mathrm{pH} 4.0$ and 7.0 buffers

\section{Determination of total titratable acidity (TTA)}

Total titratable acidity expressed as percentage of lactic acid was determined by titrating $30 \mathrm{ml}$ of the homogenate samples against $0.1 \mathrm{~N} \mathrm{NaOH}$. First, distilled water $(1 \mathrm{~L})$ was titrated with $0.1 \mathrm{NaOH}$ and the volume of $0.1 \mathrm{~N} \mathrm{NaOH}$ consumed by water titration was considered as a blank. The volume of $0.1 \mathrm{~N} \mathrm{NaOH}$ used for titration of the sample was noted after correcting the blank, and triplicate determination was made (Pearson, 1971).

$\%$ Lactic Acid $=\frac{V * 0.009008}{W} * 100$

Where: $\mathrm{V}=$ volume of $0.1 \mathrm{~N} \mathrm{NAOH}$ used for sample titration; $0.009008=$ Factor equivalent in which $1 \mathrm{ml}$ of $0.1 \mathrm{~N} \mathrm{NaOH}=0.009008 \mathrm{~g} \mathrm{C}_{3} \mathrm{H}_{6} \mathrm{O}_{5}$, weight in gram of sample in the mixture (Pearson, 1971).

\section{Proximate Composition Analysis}

Proximate composition (namely, moisture content, crude fat, fibre and ash content, crude protein content) analysis was determined by using standard procedures of Association of Official Analytical Chemists (AOAC, 2005) while total carbohydrate was calculated by difference i.e. Total carbohydrates $[\%]=100-[\%$ Moisture $+\%$ Protein + $\%$ Fat $+\%$ Ash]. Gross energy was determined by calculation from fat, carbohydrate and protein contents using the Atwater's conversion factor: $16.7 \mathrm{~kJ} / \mathrm{g}(4 \mathrm{kcal} / \mathrm{g})$ for protein, and $16.76 \mathrm{~kJ} / \mathrm{g}$ (4 $\mathrm{kcal} / \mathrm{g})$ for carbohydrates, $37.4 \mathrm{~kJ} / \mathrm{g}(9 \mathrm{kcal} / \mathrm{g})$ for fat and expressed in kilocalories $(1 \mathrm{~kJ}=4.18 \mathrm{kcal})$ (Guyot et al., 2007). 
Energy value $=(\mathrm{P} * 16.76)+(\mathrm{F} * 37.71)+(\mathrm{C} * 16.76)$ in $\frac{\mathrm{KJ}}{100 \mathrm{~g}}$ of the sample

Where:

$\mathrm{P}=$ Protein content $(\%)$.

$\mathrm{F}=$ Fat content $(\%)$.

$\mathrm{C}=$ Available total carbohydrate $(\%)$

\section{Mineral Composition Analysis}

Atomic Absorption Spectrophotometer (ICPSpectroscopy: "ULTIMA-2") was used to examine the content of calcium, iron, and zinc. After removal of organic materials by dry ashing, the residue was dissolved in dilute acid. The solution was sprayed into the flame of Atomic Absorption Spectrophotometer, and the absorption of the metal to be analyzed was measured at a specific wavelength.

Mineral content $\left(\frac{\mathrm{mg}}{100 \mathrm{~g}}\right)=\frac{[(a-b)+\mathrm{v}]}{10 W}$

Where: $\mathrm{W}=$ weight $(\mathrm{g})$ of samples; $\mathrm{V}=$ volume (V) of extract; $\mathrm{a}=$ concentration $(\mu \mathrm{g} / \mathrm{ml})$ of sample solution; $\mathrm{b}=$ Concentration $(\mu \mathrm{g} / \mathrm{ml})$ of blank solution.

Phytic acid content was determined as described by Wheeler and Ferrel (1971). The sample (0.2 g) was extracted four times for 40 min with $3 \%$ Trichloracetic acid (TCA) and then centrifuged for $30 \mathrm{~min}$ at $5000 \mathrm{rpm}$. Aliquot $(10 \mathrm{~mL})$ of the supernatant was precipitated with $4 \mathrm{~mL} \mathrm{FeCl}_{3}$ solution containing $0.2 \% \mathrm{FeCl} 3$ in $3 \%$ TCA. The solution was heated for $45 \mathrm{~min}$ in a water bath (Aston VII) at $100{ }^{\circ} \mathrm{C}$ and centrifuged at $5000 \mathrm{rpm}$ for $15 \mathrm{~min}$. The $\mathrm{Fe}(\mathrm{OH})_{3}$ obtained was dissolved in $40 \mathrm{~mL}$ of hot $3.2 \mathrm{~N} \mathrm{HNO}_{3}$ and the Iron determined calorimetrically ((Jenway Ltd Felsted, Dunmow, Essex CM6 3LB model 6051). The absorbance of the solution was read in a spectrophotometer
(Perking Elmer Lambda 3B) at $480 \mathrm{~nm}$ against a reagent blank for each set of samples. Iron content was calculated from a standard curve while phytate phosphorus from determination assuming 4:6 Iron: Phosphorus molecular ratio. Phytic acid content was determined by multiplying the phytate phosphorus content by a constant factor of 3.55 .

For the determination of tannin content, $0.2 \mathrm{~g}$ of the milled sample was weighed into a flask and $10 \mathrm{ml}$ of $4 \%$ methanol was pipetted and then the flask was closed with paraffin. The sample was then shaken for 20 minutes on a wrist action shaker before it was centrifuged for 10 minutes (4500 revolution per minute). Absorbance of the standard solution, sample extract and sample blank were read 20 minutes after incubation in the Spectrophotometer exactly at $500 \mathrm{~nm}$.

$\%$ Tannin $=\frac{A U * C s t d}{\text { Astd }}$

Where:

$\mathrm{AU}=$ Absorbance of unknown

Cstd $=$ Concentration of Standard

AStd $=$ Concentration of Standard

\section{Phytate: Mineral Molar Ratio Determination}

The mole of phytate and minerals was determined by dividing the weight of phytate and minerals with its atomic weight (phytate: $660 \mathrm{~g} / \mathrm{mole}$; Fe: $56 \mathrm{~g}$ / mole; Zn: 65g/mole; Ca: $40 \mathrm{~g} / \mathrm{mole})$. The molar ratio between phytate and mineral was obtained by dividing the mole of phytate with the mole of minerals.

\section{Functional properties}

\section{Water Absorption Index (WAI)}

Water absorption index of the samples flour were determined according to Anderson et al. 
(1969). Sample (about 1.25g) was placed in $40 \mathrm{ml}$ centrifuge tube and suspended in $15 \mathrm{ml}$ distilled water. The sample was incubated by using a shaker water bath (DKZ-1) at $25 \circ \mathrm{C}$ for 30 minutes and was centrifuged at $3000 \mathrm{rpm}$ for 5 minutes. Mass of the sample was determined before and after the decantation of the clear supernatant. The WAI was calculated as grams of absorbed water per gram of dry sample mass $(1.25 \mathrm{~g})$.

\section{WAI $=\underline{\text { Wet Sediment Weight }}$ \\ Dry Sediment Weight}

\section{Water Solubility Index (WSI)}

The supernatant preserved from WAI measurement was evaporated at $105 \circ \mathrm{C}$ for overnight. The WSI was calculated as a ratio of dry residue to the original mass (about1.25g) used to estimate WAI and the result was expressed in percentage.

\section{$\mathrm{WSI}=\underline{\text { Dry Supernatant Weight }} \times 100$}

Dry Sample Weight

\section{Determination of viscosity}

The viscosity of cooked paste was determined with a Viscometer (VISCO STAR PLUS H model). A 10\% slurry (dry matter basis) of each flour was prepared with $200 \mathrm{ml}$ distilled water, and the slurry was heated uniformly from $25^{\circ} \mathrm{C}$ to $95^{\circ} \mathrm{C}$ and held for $15 \mathrm{~min}$ and cooled to $50^{\circ} \mathrm{C}$. Then viscosity after cooling to $50^{\circ} \mathrm{C}$ was determined (Mbata et al., 2009).

\section{Data Handling and Statistical Analysis}

Summary statistics (mean and standard deviation) were computed for dependent variable. The study used proximate composition, mineral content, anti-nutritional composition, functional properties (Water Solubility Index and Water Absorption Index), and Molar ratio outcome variables and employed General Linear Model (GLM) procedure using SPSS V: 20.0 statistical software package to determine the effect of germination durations. ANOVA was used for comparisons between sample treatments, and significance was accepted at 0.05 level of probability. Whenever the treatments were found to be significant, the tukey test was used for pair wise comparisons among the different treatments at the 5\% significant level. All analysis and measurements were performed in triplicate per sample (six times per treatment).

\section{RESULTS AND DISCUSSION}

\section{Effect of Germination on pH, TTA and Proximate composition}

Our result, summarized in Table 1, revealed that the $\mathrm{pH}$ of both varieties significantly $(\mathrm{p}<0.05)$ decreased as the germination hour increased from 24 to 48 hours. Consequently, an increase in TTA of both sorghum varieties was observed starting from 24 hours of germination.

Girana and Misker sorghum varieties showed a $9.68 \%$ and $9.52 \%$ reduction in $\mathrm{pH}$ at 72 hours of germination. As a result, at 72 hours germination, TTA increased significantly $(\mathrm{P}<0.05)$ from $0.19 \pm 0.01$ to $0.29 \pm 0.13$ and from $0.25 \pm 0.04$ to $0.3 \pm 0.09$ for Girana and Misker varieties respectively. Such increase in acidity of germinated sorghum flour could be as a result of hydrolysis of some complex organic molecules. Gernah et al. (2011) and Gibson et al. (2010) explained that low $\mathrm{pH}$ prevents the growth of pathogenic 
microorganisms, while the organic acids have the potential to form soluble ligands with iron and zinc, thus enhancing absorption.

At the 24 hours germination, the moisture contents of flour of Girana and Misker sorghum varieties significantly $(\mathrm{p}<0.05)$ increased from $7.46 \pm 0.11$ to $8.33 \pm 0.09$ and from $7.33 \pm 0.03$ to $8.43 \pm 0.05$ respectively. However, there was no significant difference in moisture content after 24 hour germination (Table 1). This probably is as a result of absorption of water to the grains during the germination process.

As indicated in Table 1, a significant $(p<0.05)$ increase of protein content was noticed starting from 24 hour germination. And after 72 hour germination, the protein content increased from $10.35 \pm 0.04 \%$ to $12.59 \pm 0.15$ for Girana variety. However, Misker variety shows a significant increase in protein content at 48 hours of germination and - even though it is not statistically different from 48 hours germination - at the 72 hours germination the protein content increased from $10.17 \pm 0.02$ to $12.75 \pm 0.136$. The most probable reason for this increase in protein content could be during germination protease enzyme increases that result in the degradation of peptide component to amino acids which in turn leads to an increase in protein content. An increase in proteins content following germination of sorghum and "Acha" and finger millet have been reported (Inyang and Zakari, 2008; Laetitia et al., 2005; Nzelibe and Nwasike, 1995).

We found a significant $(\mathrm{p}<0.05)$ reduction in the crude fat content at 24 hours of germination. As shown in table 1, after 72 hour germination, the fat content decreased from $3.67 \pm 0.06$ to $2.72 \pm 0.06$ and from $3.73 \pm 0.21$ to $2.64 \pm 0.03$ for Girana and
Misker varieties respectively. Inyang and Zakari (2008), Kiranawati (2002) and Kikafunda et al. (2006) also reported a decrease in fat content during germination of pearl millet, bean and maize respectively. The most probable reason for a decrease in fat content during germination might be the increased activity of lipolytic enzymes during germination, which hydrolyzed the fats into fatty acid and glycerol. Since these compounds are water soluble, they can diffuse into the cells tissue (Onweluzo and Nwabugwu, 2009).

Likewise, a significant $(\mathrm{p}<0.05)$ decrease in ash content at 24 hours and 48 hours of germination was observed for Girana and Misker varieties respectively. After $72 \mathrm{hr}$ period of germination, the ash content showed reduction from $1.66 \pm 0.01$ to $1.50 \pm 0.08$ and from $1.50 \pm 0.01$ to $1.32 \pm 0.04$ for Girana and Misker varieties respectively. Mubarak (2005) also reported a significant decrease in ash content of mung bean seeds following germination and cooking processes. The probable reason for this decrease in ash content during germination might be leaching of minerals during steeping and washing.

Our result also revealed a significant $(\mathrm{p}<0.05)$ decrease in crude fibre content at 24 to 48 hour germination for both varieties. This result is consistent with Moharram and Youssef (1995) and El Maki et al. (1999) who reported that part of the seed fiber may be solubilized enzymatically during seed germination. Dicko et al. (2006) also suggested that germination may increase activity of $\beta$-amylase enzyme which hydrolyzes cell wall of carbohydrates during germination.

The carbohydrates content of the un-germinated sorghum seeds of both varieties were $74.66 \pm 0.07$ and $75.11 \pm 0.21$ for Girana and Misker 


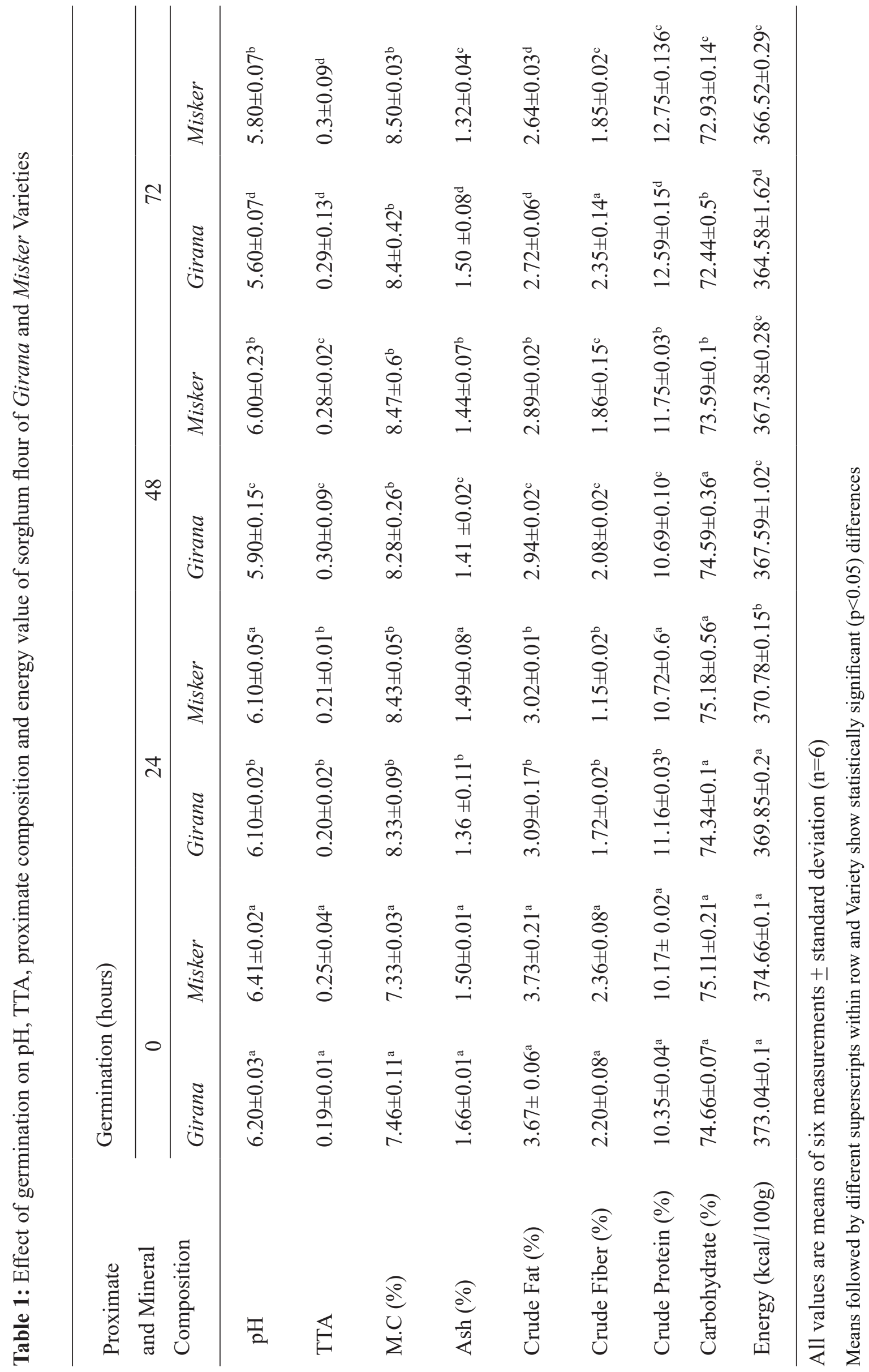


varieties, respectively. And after 72 and 48 hours of germination the carbohydrate content of Girana and Misker varieties reduced significantly $(\mathrm{p}<0.05)$ to $72.44 \pm 0.5 \%$ and $73.59 \pm 0.1$. This significant reduction could be attributed to metabolism. The carbohydrates may have been digested into simple sugars by amylolytic enzymes which are rapidly taken up by the growing embryo to serve as its energy source during germination (Elkhier and Hamid, 2008). As a result of reduction in crude fat and carbohydrate content after 72 hours germination, a significant $(p<0.05)$ decrease in energy content from $373.04 \pm 0.1$ to $366.52 \pm 0.29$ and from $374.66 \pm 0.96$ to $364.58 \pm 1.62$ was observed for Girana and Misker varieties, respectively.

\section{Effects of Germination on Mineral Content}

As indicated in Table 2, germination results in a significant $(p<0.05)$ increase of iron from $7.15 \pm 0.03$ to $7.51 \pm 0.23$ and from $7.42 \pm 0.1$ to $7.85 \pm 0.17$ at 48 hours for Girana and Misker varieties, respectively. The probable reason for this increment could be reduction in polyphenols (phytate and tannins) during germination that may liberate the bound iron result in an increase in concentration. However, the content of iron returned to the initial concentration after 48 hours of germination.

When considering calcium, germination resulted in a slight decrease $(16.68 \pm 0.0-16.56 \pm 0.06)$ in the calcium content of only Girana variety at 24 hours germination followed by no effect of germination on calcium content of both sorghum varieties. This result is in agreement with the findings of Elisa and Adelaide (2009) who reported that soaking did not affect the calcium content of the soybeans.
Like what was found for calcium, germination had no effect on zinc content. The same result for soaked soybeans was reported by Lestienne et al. (2005). According to Weaver and Kannan (2002), zinc forms the most stable complex with phytate and protein in the cells of the cotyledon of the grain, and thus it is the most affected mineral in terms of bioavailability.

\section{Effects of Germination on Anti-nutritional}

Content

As indicated in Table 2, germination under the conditions used in this study resulted in a considerable reduction of phytic acid. The result showed that, after 72 hour germination, there was a significant $(\mathrm{p}<0.05) 51.8 \%(416.08 \pm 2.20$ - $\quad 215.41 \pm 0.98) \quad$ and $\quad 47.4 \% \quad(455.83 \pm 2.04$ $-216.42 \pm 0.76)$ reduction in phytate content of Girana and Misker varieties, respectively. Dicko et al. (2005) explained that the reason for the decrease in phytic acid content during germination may be an increase in the phytase activity, which degrades phytic acid in plant-based foods. This result agrees with the findings of Tizazu et al. (2010), Liang et al. (2008), Maghoub and Elhag (1998) and Inyang and Zakari (2008) who reported a decrease in phytate following germination of sorghum based complementary food: milling, soaking, malting, heat-treatment and fermentation of sorghum; soaking, germination and fermentation of rice; germination and fermentation of pearl millet, respectively. However, Helmalatha et al. (2007) reported no degradation of phytate after germination of finger millet for 48 hours.

Like what was found for phytate, germination had a profound effect on the reduction of tannin content of both sorghum varieties. Accordingly, the present 


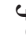

. $\mid$ |

政

7

tั.

:

进

중

ธี

.0:

फ़

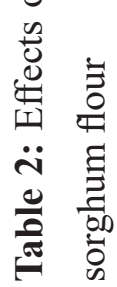

さ

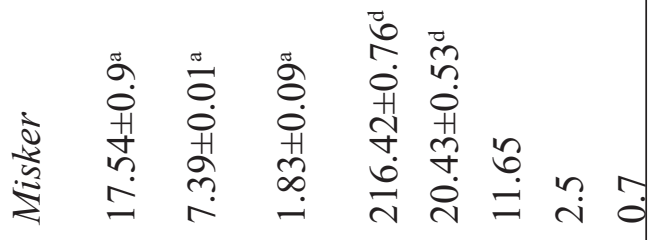

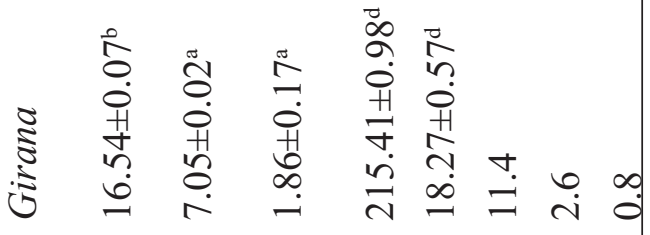

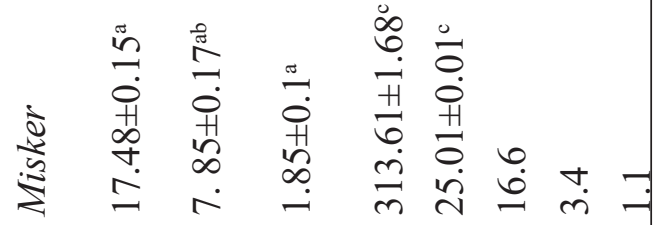

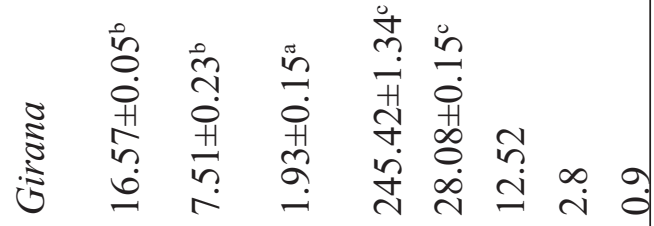

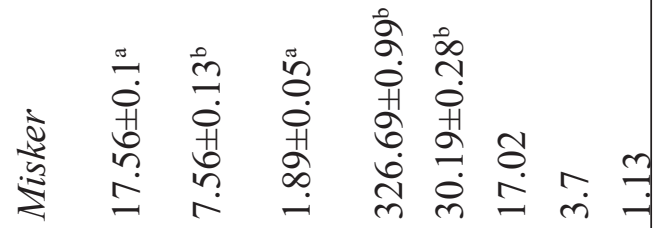

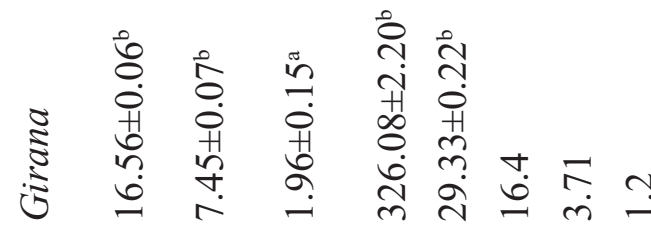

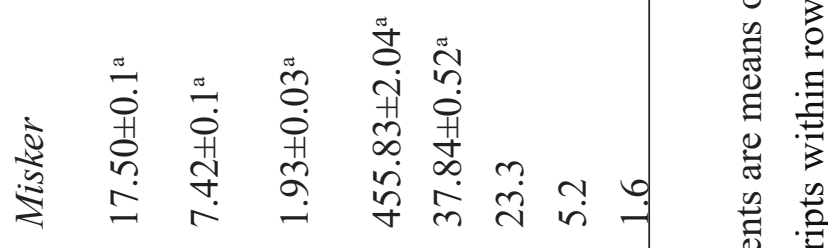

कृ

|

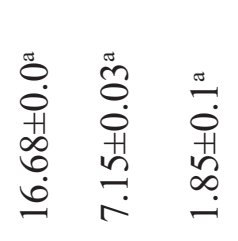

華

满

$\frac{0}{5}$
$\vdots$
$:$

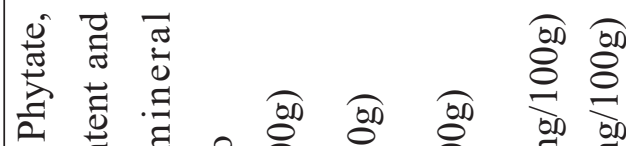

की

药

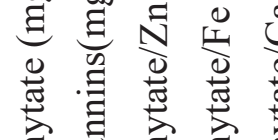

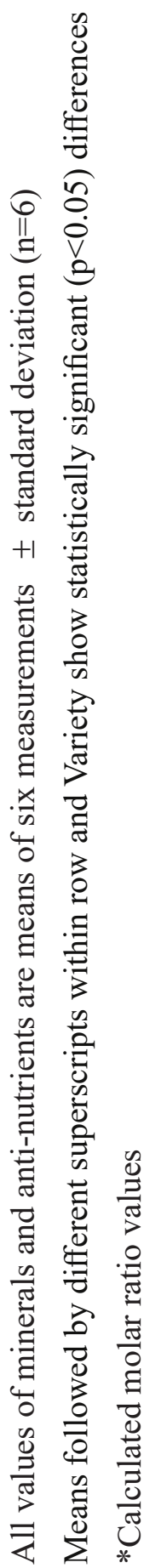


study found a $52 \%(35.17 \pm 0.13-18.27 \pm 0.57)$ and a $54 \%(37.84 \pm 0.52-20.43 \pm 0.53)$ reduction in tannin content of Girana and Misker varieties after 72 hours of germination, respectively. Tannins have been found to inhibit digestive enzymes and thereby lower digestibility of most nutrients, especially protein (Ali et al., 2009; Michaelsen et al., 2008). According to Mbithi-Mwikya et al. (2000), the observed reduction in tannin content in germinated seeds has been attributed to the formation of hydrophobic associations of tannins with seed proteins and enzymes, not to actual loss or degradation of tannins per se. However, Shimelis and Rakshit (2008) explained that a decrease in tannin content during germination may be due to the leaching of tannins in the sprouting medium and as a result of decreased activity of polyphenol oxidase and of other catabolic enzymes. Hotz and Gibson (2007) also stated that certain tannins and other polyphenols in legumes and sorghum may also be reduced during germination as a result of formation of polyphenols complexes with proteins and the gradual degradation of oligosaccharides. Such reductions in polyphenols may facilitate iron absorption.

\section{Effects of Germination on Phytate: Mineral Molar Ratio}

To make sense out of the relation between antinutrient and minerals, such as suggest interpreting the result as molar ratio between the anti-nutrients and the minerals. . Accordingly, as indicated in Table 2 phytate/zinc molar ratio decreased continuously from 22.64 to 11.4 and 23.3 to 11.65 for Girana and Misker varieties, respectively as germination duration is extended to 72 hours. Considering phytate/zinc molar ratio $<15$ as critical limit for absorption, after germination duration of 24 hours the phytate/Zinc molar ratio of both varieties decreased to $<15$ which indicates the positive contribution of germination in improving bioavailability of zinc. The contribution of this reduction in phytate/zinc molar ration to bioavailability of Zinc is that if the phytate/zinc molar ratio is $>18$, zinc absorption was estimated to be $18 \%$ and $25 \%$ for adult males and females, respectively, whereas for diets with phytate/zinc molar ratios between 4 and 18, the corresponding zinc absorption was estimated to be $26 \%$ and $34 \%$ for adult males and females, respectively (Hotz and Brown, 2004). Gibson et al. (2010) explained that the reduction in Phytate/zinc molar ratio is due to the degradation of phytate in cereal and/or legume and linked with significant increases of Zinc.

When considering a reduction in molar ratio of phytate/iron, germination caused a reduction in molar ratio of phytate/iron from 4.94 to 2.6 and from 5.2 to 2.5 for Girana and Misker varieties, respectively. However, based on the previously mentioned critical limit, since the molar ratio of phytate/iron beyond 72 hours germination was $>1.00$ (critical limit for absorption) sorghum products from the two varieties will have poor bioavailability of iron. As mentioned earlier during the 72 hours germination duration only nearly $50 \%$ of the phytate was removed and the inhibitory effect of phytic acid on iron absorption even at very low phytate concentrations (as low as 0.2:1.0) was reported by Hallberg et al. (1989) who suggested that, where possible, all of the phytate should be degraded from cereal-legume based foods to achieve the maximum benefit of a four- to fivefold increase in nonheme iron absorption.

Though there was a significant reduction in phytate/calcium molar ratio, in the present study a molar ratio for phytate/calcium of $>0.24$ (critical limit for absorption) was obtained for both varieties 
after 72 hours of germination. These ratios predict that sorghum-based products from the studied varieties may be affected by poor bioavailability of calcium. This could be due to the high content of phytate in sorghum which affects the mineral bioavailability.

\section{Effects of Germination on Functional Properties}

Table 3 summarizes the effect of germination on water absorption index, water solubility index and viscosity of sorghum flour of Girana and Misker varieties.

Water absorption index (WAI) measures the volume occupied by the starch after swelling in excess water, which corresponds to the volume of the gel formed. After 72 hour duration of germination the water absorption index (WAI) significantly $(\mathrm{P}<0.05)$ increased from $1.27 \pm 0.05$ to $1.69 \pm 0.02$ and $1.02 \pm 0.03$ to $1.49 \pm 0.05$ for Girana and Misker varieties, respectively. This result has parallels with the report of Ghavidel and Prakash (2006), who worked with cowpea, green gram, lentil and bengal gram and noted an increase in WAI following germination. Gamel et al. (2006) explained that an increase of WAI on germination could be attributed to an increase in protein content, a change in the quality of protein upon germination and a breakdown of polysaccharide molecules; hence, the sites for interaction with water and holding water would increase.

Water solubility index (WSI) is related to the amount of soluble solids, which is often used as an indication of degradation of starch molecules, and dextrinisation (Guhua et al., 1997). After 72 hours of germination for both Girana and Misker varieties, the water solubility index increased significantly $(\mathrm{P}<0.05)$ from $9.17 \pm 0.08-9.66 \pm 0.19$ and from $9.23 \pm 0.41-9.66 \pm 1.7$, respectively. Similar increase in WSI after germination was reported by Achinewhu (1986) and Amadi et

Table 3: Effects of germination on WAI, WSI and Viscosity of Girana and Misker Sorghum Varieties

\begin{tabular}{|c|c|c|c|c|c|c|}
\hline \multirow{2}{*}{$\begin{array}{l}\text { Germination } \\
\text { time (hours) }\end{array}$} & \multicolumn{2}{|c|}{ WAI } & \multicolumn{2}{|c|}{ WSI } & \multicolumn{2}{|l|}{ Viscosity } \\
\hline & Girana & Misker & Girana & Misker & Girana & Misker \\
\hline 0 & $1.27 \pm 0.05^{\mathrm{a}}$ & $1.02 \pm 0.03^{\mathrm{a}}$ & $9.17 \pm 0.08^{\mathrm{a}}$ & $9.23 \pm 0.41^{\mathrm{a}}$ & $387.30 \pm 0.06^{\mathrm{a}}$ & $385.70 \pm 0.51^{\mathrm{a}}$ \\
\hline 24 & $1.35 \pm 0.04^{\mathrm{b}}$ & $1.10 \pm 0.06^{\mathrm{b}}$ & $9.54 \pm 0.06^{\mathrm{b}}$ & $9.37 \pm 0.14^{\mathrm{ac}}$ & $207.01 \pm 0.57^{b}$ & $194.45 \pm 0.12^{b}$ \\
\hline 48 & $1.62 \pm 0.42^{\mathrm{c}}$ & $1.31 \pm 0.03^{c}$ & $9.60 \pm 0.07^{\mathrm{b}}$ & $9.55 \pm 0.07^{\mathrm{ac}}$ & $172.40 \pm 0.05^{\mathrm{c}}$ & $158.37 \pm 0.06^{\mathrm{c}}$ \\
\hline 72 & $1.69 \pm 0.02^{\mathrm{d}}$ & $1.49 \pm 0.05^{\mathrm{d}}$ & $9.66 \pm 0.19^{\mathrm{c}}$ & $9.66 \pm 1.7^{c}$ & $107.93 \pm 0.63^{d}$ & $112.31 \pm 0.06^{\mathrm{d}}$ \\
\hline
\end{tabular}

All values are means of six measurements \pm standard deviation $(n=6)$

Means followed by different superscripts within column show statistically significant $(\mathrm{p}<0.05)$ differences 
al. (1999). According to Odunfa (1985) the probable reason for this increment in WSI may be due to degradation of high molecular weight carbohydrates and proteins to simpler more soluble components during the process.

The viscosity of ungerminated Girana and Misker varieties was $387.30 \pm 0.06$ and $385.70 \pm 0.51$, and it reduced significantly $(\mathrm{p}<0.5)$ with germination time where the lowest viscosity, which is $107.93 \pm 0.63$ and $112.31 \pm 0.06$, was observed for Girana and Misker varieties, respectively. During germination, the starch is degraded by the action of enzymes present in the seed. Amylases break down the amylose and amylopectin components of the starch producing smaller dextrins, maltose and glucose, and thus reducing the viscosity (Gibson et al., 2006).

\section{CONCLUSIONS}

The present study demonstrated the potential of household practices such as germination as simple and feasible options for low-income countries like Ethiopia to enhance mineral bioavailability and improve protein content - the two main reasons for the major forms of malnutrition. However, the observed increase in protein content, the improvement in bioavailability of minerals and the reduction in fat, ash, fiber, Carbohydrate and energy value call attention in optimizing germination duration based on the concerned nutrient. The study showed that the nutritional value and the functional properties of sorghum can be improved while anti-nutritional content of sorghum can be reduced by using low-cost household practices. Sorghum can be used as a potential raw material in food processing industry for production of sorghum flours or grits, weaning mixtures and supplementary sorghum-based value added products including fortified and culinary products that are affordable for most consumers. Though there was a small variation between the two sorghum varieties, the present study suggests that nutritional value and anti-nutritional content of varieties should be considered in addition to yield factor in the selection of varieties released from agricultural research centers.

\section{ACKNOWLEDGEMENT}

The authors would like to thank Amhara Agricultural Research Institute (ARARI) and Sirinka Agricultural Research Centre for providing access to sorghum varieties.

\section{REFERENCES}

Achinewhu, S. C. (1986). Some biochemical and nutritional changes during the fermentation of fluted pumpkin (Telferia occidentalis). Qualitars Plantarum: Plant Foods for Human Nutrition 36: 97-107.

Ali, N. M. M., Tiny, E.l., Elkhalifa, A. H. A. E. O., Salih, O. A. and Yousif, N. E. (2009). Effect of alkaline pretreatement and cooking on protein fractions of a high-tannin sorghum cultivar. Journal of Food Chemistry 114: 649-651.

Amadi, E. N., Barimalaa, I. S. and Omosigho, J. (1999). Influence of temperature on the fermentation of bambara groundnut (Vigna subterranean) to produce a dawadawa-type product. Plant Foods for Human Nutrition 54: 13-20. 
AOAC (2005). Official Methods of Analysis $16^{\text {th }}$ ed. Association of Official Analytical Chemists, Arlington V.A, pp 806-842.

Asfaw Adugna, Tesfaye Tefera and Abera Deresa. (2005). Sorghum Production and Research Experiences. EARO, Addis Ababa, Ethiopia. Pp $1-32$.

Atwell, W.A., Hyldon, R.G., Godfrey, P.D., Galle, E.L., Sperber, W.H., Pedersen, D.C., Evans, W.D. and Rabe, G.O. (1988). Germinated quinoa flour to reduce the viscosity of starchy foods. Cereal Chemistry 65: 508-509.

Davidson, S., Passmore, R., Brock, J.F. and Truswell, A.S. (1979). Millets. In: Human Nutrition and Dietetics. Churchill Livingstone, pp. 175.

Dicko, M.H., Gruppen, H., Zouzouho, O.C., Traore, A.S., Van Berkel, W.J.H. and Voragen, A.G.J. (2005). Evaluation of the Effect of Germination on Phenolic Compounds and Antioxidant Activities in Sorghum Varieties. J. Agricultural and Food Chemistry. 53:2581-2588.

Dicko, M.H., Gruppen, H., Zouzouho, O.C., Traore, A.S., Van Berkel, W.J.H. and Voragen, A.G.J. (2006). Effect of germination on the activities of amylases and phenolic enzymes in sorghum varieties grouped according to food end - use properties. Journal of the Science of Food and Agriculture. 86:953-963.

Elisa, N.L.K. and Adelaide, B. (2010). Effect of soaking and cooking on phytate concentration, minerals, and texture of food-type soybeans. Ciênc. Tecnol. Alimentos 30(4): 1056-1060.

Elkhier, M.K.S. and Hamid, A.O. (2008). Effect of malting on the chemical constituents, antinutrition factors and ash composition of two sorghum varieties (feterita and tabat) grown in Sudan. Research Journal of Agriculture and Biological Sciences 4:500-504.

El Maki, H.B., Babiker, E.E. and Tinay A.H. (1999). Changes in chemical composition, grain malting, starch and tannin contents and protein digestibility during germination of sorghum varieties. Food Chem. 64:331-336.

FAO (2006). Official Agricultural statistics 18th edition: Food and Agricultural Organization of United Nation, pp 1002 - 1004

Gamel, T.H., Linssen, J.P., Mesallam, A.S., Damir, A.A. and Shekib, L.A. (2006). Seed treatment affect functional and antinutritional properties of amaranth flours, Journal of the Science of Food and Agriculture. 86:1095-1102.

Ghavidel, R.A. and Prakash. J. (2006). Effect of germination and dehulling on functional properties of legume flours. Journal of the Science of Food and Agriculture. 86:1189-1195.

Gibson, R.S., Perlas, L. and Hotz, C. (2006). Improving the bioavailability of nutrients in plant foods at the household level. Proceedings of the Nutrition Society. 65:160-168.

Gibson, R.S., Bailey, K.B., Michelle, G. and Ferguson, E.L. (2010). A review of phytate, iron, zinc, and calcium concentrations in plantbased complementary foods used in low-income countries and implications for bioavailability. Food and Nutrition Bulletin. 31(2): S134-146.

Guhua, M., Ali, Z.S. and Bhattacharya, S. (1997). Twin-screw extrusion of rice flour without a die: Effect of barrel temperature and screw speed on extrusion and extrudate characteristics. Journal of Food Engineering 32 (3):251-267. 
Guyot, J.P., Rochette, I. and Treche, S. (2007).

Effect of fermentation by amylolytic lactic acid bacteria, in process combinations, on characteristics of rice/soybean slurries: A new method for preparing high energy density complementary foods for young children. Food Chemistry.100:623-63.

Egli, I., Davidsson, L., Juillerat, M.A., Barclay, D. and Hurrell, R. (2002). The influence of soaking and germination on the phytase activity and phytic acid content of grains and seeds potentially useful for complementary feeding. Journal of Food Scence. 67: 3484-8.

Hallberg, L., Brune, M. and Rossander L (1989). Iron absorption in man: ascorbic acid and dosedependent inhibition by phytate. American $J$ Clin Nutr.49:140-144

Helmalatha. S, Platel, K. and Srinivasan K (2007). Influence of germination and fermentation on bioaccessability of zinc and iron from food grains. Eur. J. Clin. Nutr. 61:342-348.

Hotz, C. and Brown, K.H. (2004). International Zinc Nutrition Consultative Group (IZiNCG) Technical Document \#1. Assessment of the risk of zinc deficiency in populations and options for its control. Food Nutr Bull. 25:S99-199.

Hotz, C. and Gibson, R.S. (2007). Traditional food processing and preparation practices to enhance the bioavailabilty of micronutrients in plantbased diets. Journal of nutrition. 137:10871100.

Inyang, C.U. and Zakari, U.M. (2008). Effect of germination and fermentation of pearl millet on proximate, chemichal and sensory properties of instant "Fura" - A Nigerian cereal food. Pakistan Journal of Nutrition.7 (1): 9-12.
Kikafunda, J.K., Abenakyo, L. and Lukwago, F.B. (2006) Nutritional and sensory properties of high energy/nutrient dense composite flour porridges from germinated maize and roasted beans for child-weaning in developing countries: a case for Uganda. Ecol. Food Nutr.45:279-294.

Kiranawati, T.M. (2002). The quality evaluation of sprouts bean milk (Vigna unguiculata L.). Malang, Indonesia Brawijaya University, Unpublished Master thesis.

Laetitia, M.M., Joseph, H.D., Joseph, D. and Christian, M. (2005). Physical, chemical and microbiological changes during natural fermentation of "gowe", a sprouted or nonsprouted sorghum beverage from West Africa. African Journal of Biotechnology. 4(6):467496.

Lestienne, I., Icard-Verniere, C., Mouquet, C., Picq, C. and Treche, S. (2005). Effect of soaking whole cereal and legume seeds on iron, zinc and phytate contents. Food Chem. 89: 421-425.

Liang, J., Han, B. Z., Nout, M.J.R. and Hamer RJ (2008). Effects of soaking, germination and fermentation on phytic acid, total and in vitro soluble zinc in brown rice. FoodChem. 110:821-828

Maghoub, S.E.O. and Elhag, S.A. (1998). Effect of milling, soaking, malting, heat-treatment and fermentation on phyate level of four Sudanese sorghum varieties. Food Chem. 61:77-80.

Mbithi-Mwikya, S., Camp, J.V., Yiru, Y. and huyghebaert, A. (2000). Nutrient and antinutrient changes in finger millet (Eleusine coracan) during sprouting. Lebensm. Wiss.U. Technology.33:9-14. 
Michaelsen, k.F., Camilla, H., Nanna, R., Pernille, K., Maria, S., Lotte, L., Christain, M., Tsinuel, G. and Henrik, F. (2008). Choice of foods and ingredients for moderately malnourished children 6 months to 5 years old. Food and Nutrition Bulletin. 30(3): S343-403.

Moharram, Y.G. and Youssef, A.M.A. (1995). Sorghum grain and quality of its edible products. In: Charalambous G (Ed.). Food Flavors: Generation, Analysis and Process Influence, Developments in Food Science.Elsevier Applied Science. 37:111-146.

Mubarak, A.E. (2005). Nutritional composition and antinutritional factors of mung bean seeds (Phaseolus aureus) as affected by some home traditional processes. Food Chem.89:489-495.

Nzelibe, H.C. and Nwasike, C.C. (1995). The Brewing Potential of "Acha" (Digitaria exius) Malt Compared With Pearl Millet (Pennisetum typhoides) Malts and Sorghum (Sorghum bicolor) Malts. Journal of the Institute of Brewing. 101:345- 350.

Odunfa, S.A. (1985). Microbiological and toxicological aspects of fermentation of castor oil seeds for Ogiri Production. J. Food Sci. 50: 1758-1759.

Pearson, D. (1971). The chemical Analysis of Foods. 6th Edition. Chemical publishing company, Inc. New York.

Raihanatu, M.B., Modu, S., Falmata, A.S., Shettima,Y.A. and Heman, M. (2011). Effect of processing (sprouting and fermentation) of five local varieties of sorghum on some biochemical parameters. Biokemistri 23 (2): $91-96$
Rooney, L.W. and Waniska, R.D. (2004). Crop utilization and marketing: Food and Nutrition quality of sorghum and millet, Report project. Texas A and M University College.

Shashi, B.K., Sharan, S., Hittalaman, S., Gshankarandt, A. and Nagarathna, K. (2007). Micronutrient composition, antinutritional factors and bioaccessibilty of iron in different finger millet (Eleusine corcana) genotypes. Karnataka journal of agriculture science. 20(3): 583-585.

Shimelis, E.A. and Rakshit, S.K. (2008). Influence of natural and controlled fermentations on-galactosides, antinutrients and protein digestibility of beans (Phaseolus vulgaris L.). International Journal of Food Science and Technology.43:658:665.

Tizazu, S., Kelbesa, U., Cherenet, A. and Nigussie, R. (2010). Improvement of energy and nutrient density of sorghumbasedcomplementary foods using germination. African journal of food agriculture nutrition and development. 10(8):2928-2942.

Walter, H.L., Fanny, L., Charles, C. and Christian, R. (2002). Minerals and phytic acid interaction: is it a real problem for human nutrition. Int $J$ Food Sc Tech. 37:727-739.

Weaver, C.M. and Kannan, S. (2002). Phytate and mineral bioavailability.In: Reddy NR, Sathe SK (eds). Food Phytates.pp 211-223. 